Historic, Archive Document

Do not assume content reflects current scientific knowledge, policies, or practices. 



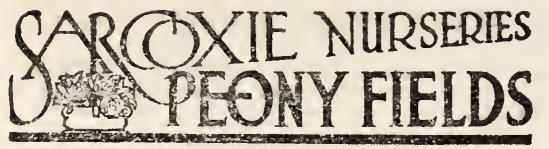

WILD BROS. NURSERY CO.

\section{SARCOXIE, MISSOURI}

\section{PEONIES}

Prices are for good strong divisions of 3 to 5 eyes, from blooming plants. We consider them fully equal to one-year plants, they cost less and average larger than the one-year plants usually sent out. If you want something larger order 5 to 8 eyes at $50 \%$ advance, or 8 to 10 eyes at double the printed price.

Augustin d'Hour. Deep, rich, brilliant red; midseason; medium tall; fine. $\$ 1.00$ each.

Baroness Schroeder. Large; delicate flesh becoming white; fragrant; midseason. $75 \mathrm{c}$ each.

Canari. Sulphur-white becoming pure white large ; fragrant; midseason. $40 \mathrm{c}$ each ; $\$ 4.00$ per doz.

Crown of Gold; Couronne d'Or. White flecked carmine ; immense ; fragrant ; late ; vigorous. $40 \mathrm{c}$ each; $\$ 4.00$ per doz.

Duc de Cazes. Carmine red, center deep rose; midseason; medium size; blooms freely. $35 \mathrm{c}$ each; $\$ 3.50$ per doz.

Duchess de Nemours. Ivory-white; medium early; vlgorous; blooms freely. $35 \mathrm{c}$ each; $\$ 3.50$ per doz.

Duchess d'Orleans. Carmlne pink, center pink and salmon, becoming amber-yellow; fragrant; vigorous. $30 \mathrm{c}$ each; $\$ 3.00$ per doz.

Duke of Wellington. Sulphur becoming pure white; very large ; fragrant; very full; late ; blooms freely. $40 \mathrm{c}$ each ; $\$ 4.00$ per doz.

Edulis superba. Brilliant deep rose-pink; very fragrant; large, of good form; extra early ; vigorous. $35 \mathrm{c}$ each ; $\$ 3.50$ per doz.

Felix Crousse. Brilliant, rich, dazzling rubyred; large ; compact ; fragrant; midseason ; fine. $75 \mathrm{c}$ each; $\$ 7.50$ per doz.

Festiva maxima. Pure white, central petals flecked carmine; very early; vigorous. You can't plant too many. $50 \mathrm{c}$ each ; $\$ 5.00 \mathrm{pr}$. doz.

Madame Calot. Delicate pink, becoming white; fragrant; large; early. 40c each ; $\$ 4.00$ doz.

Madame de Verneville. Large, compact, very full; white, flecked carmine; rose fragrance; very early; vigorous; extra fine. $40 \mathrm{c}$ each ; $\$ 4.00$ per doz.

Octave Demay. Delicate hydrangea-pink; large ; fragrant; early; rather dwarf. $75 \mathrm{c}$ each.

Queen Emma. Bright light pink; large, very full; midseason to late; blooms freely. $75 \mathrm{c}$ each.

Therese. Very large; satiny-pink becoming lilac-white in the center; very fragrant; compact. $\$ 3.00$ each.

Zoe Calot. Very large, very full, globular bloom; soft pink, tinted lilac; fragrant; midseason. $30 \mathrm{c}$ each; $\$ 3.00$ per doz.

\section{PENNANT MIXED PEONIES}

If you want something good at a moderate price and are not particular what varieties and colors, just so they are nice, order Pennant Mixed. This is not a cheap lot of undesirable varieties, but a really first class mixture of good named Peonies, the leading commercial varieties predominating. Do not ask for certain colors of these as they are grown mixed. $25 \mathrm{c}$ each; $\$ 2.00$ per doz.; 50 or more at $16 \mathrm{c}$ each.
BULLETIN B, FEB. 1931

Please tell us when you wish shipment, and whether by freight, express or parcel post, otherwise we use our judgment. Don't forget to tell us freight or express office if different from postoffice. Postage additional except where quoted postpaid. Your orders will have our careful attention.

\section{PEONY SURPRISE COLLECTION}

\section{6 for $\$ 2.50 ; 12$ for $\$ 4.50$}

Six good named Peonies, all different, our selection, for $\$ 2.50$; or 12 , not less than 6 varieties, for $\$ 4.50$. Postage additional.

\section{LIBERTY IRISES; Fleur-de-Lis}

Liberty Irises are perfectly hardy, easy to grow, increase rapidly, grow in almost any soil, usually bloom the first spring and furnish a wealth of color in May.

Price: $15 \mathrm{c}$ each; 3 of a kind for $40 \mathrm{c}$; 6 or more of a kind at $\$ 1.50$ per doz., except as otherwise quoted. Postage additional if by parcel post.

Albert Victor. Soft blue and lavender. 36 in.

Alcazar. Standards light bluish-violet, falls purple; fine. $30 \mathrm{c}$ each; $\$ 3.00$ per doz.

Ambassadcur. Standards smoky reddish-lavender, falls dark purplish-maroon. $40 \mathrm{c}$ each.

B. Y. Morrison. Standards lavender-violet, fall's velvety-purple, bordered lavender. $50 \mathrm{c}$ each.

Caprice. Standards cerise, falls deeper ; early ; blooms freely. 20c each; $\$ 2.00$ per doz.

Celeste. Sky-blue, deeper falls; midseason.

Cluny. Soft bluish-violet, falls deever; large ; early ; fragrant. $60 \mathrm{c}$ each.

Col. Candelot. Standard bronze, overlaid rerldish-lavender, falls velvety-crimson. $40 \mathrm{c}$ each.

Crimson King. Rich claret-purple; 24 in ; good.

Dr. Bernice. Standards coppery-bronze, falls velvety-crimson; 2 feet.

Dream. Soft pink tinged lavender; fragrant vigorous; blooms freely; excellent. $40 \mathrm{c}$ each.

Edouard Michel. Standards violet-red, falls deeper; excellent form; fragrant. 70c eacl.

Fairy. White, shaded soft blue ; fragrant.

Florentina. White, tinged lavender; early; $2 \mathrm{ft}$.

Honorabilis. Gold and crimson-brown; early to late.

Iris King. Standards old gold, falls velvetygarnet brown, shaded ox-blood-red, borderei yellow ; 24 in.

Khedive. Beautiful soft lavender; 30 in.

Kochi. Velvety royal reddish-purple; very early.

Lent A. Williamson. Standards lavender-violet, falls velvety-purple. $40 \mathrm{c}$ each; $\$ 4.00 \mathrm{pr}$. doz. Lorely.. Standards light yellow, falls purple bordered yellow; early ; $21 / 2 \mathrm{ft}$.

Mme. Chereau. White frilled violet-blue.

Mne. Chobaut. White tinged yellow, shaded reddish-brown and lilac. $40 \mathrm{c}$ each.

Mme. Pacquitte. Bright rosy-claret; early ; tall. Monsignor. Bluish-violet, falls veined reddishpurple and white; large; late.

Mother of Pearl. Light bluish-lavender, pearly effect; fragrant. $30 \mathrm{c}$ each; $\$ 3.00$ per doz.

Mrs. H. Darwin. White, base veined violet.

Pailida Dalmatica. Lavender-blue, falls deeper ; very beautiful. 20c each; $\$ 2.00$ per doz.

Perfection. Standards lavender-blue, falls velvety violet-black; vigorous.

Princess Victoria Louise. Standards sulphur, falls reddish-purple bordered cream.

Prosper Laugier. Standards reddish-bronze, falls velvety ruby-purple. $20 \mathrm{c}$ each; $\$ 2.00 \mathrm{pr}$. doz.

Prospero. Standards lavender, suffused yellow at base, falls purple tinged reddish. 50c each. 


\section{LIBERTY IRISES-Continued}

Quaker Lady. Standards smoky-lavender, falls agelatum-blue. $35 \mathrm{c}$ each; $\$ 3.50$ per doz.

Queer of Biay. Lilac to orchard-nink; excellent.

Rhein Nixe. Standards white, falls rich pansyviolet edged white.

Roseway. Standards purplish-rose, falls deeper: fragrant. $45 \mathrm{c}$ each; 3 for $\$ 1.25$.

Sappho. Standards violet-blue; falls royal nurple.

Seminole. Standards violet-red, falls velvetymahogany-red to deep crimson; one of the brightest. $35 \mathrm{c}$ each; 3 for $\$ 1.00$.

Sherinah. Clear soft yellow, center deeper; 4 ic each ; 3 for $\$ 1.25$.

Sherwin Wright. An excellent golden-yellow.

Sweet Lavender. Standards lavender-violet,ruffled, fal!s reddish-violet. $75 \mathrm{c}$ each ; 3 for $\$ 2$.

Violacea grandiflora. Standards lavender-blue, falls almost violet-blue; excellent.

Wallalla. Standards lavender, falls violet-purple.

\section{SPECIAL IRIS COLLECTION F}

Assorted, our selection, named: 6,3 varieties, $60 \mathrm{c}$ (nostpaid 75c); 12,6 varieties, $\$ 1.00$ (postpaid $\$ 1.25$ ) ; 25,8 varieties, $\$ 2.00$ (postpaid $\$ 2.40$ ) ; 100,8 varieties, $\$ 6.50$ (postpaid $\$ 7.75)$.

\section{JAPANESE IRISES}

The Japanese differ from Liberty in size, flatness of flower and breadth of petal, and bloom later. Plant in full sun. Water must wot stand on roots. Six-petaisd are double. Blue Early; double, $25 \mathrm{c}$ each: $\$ 2.50$ per doz. Crimson-purple. Double. $25 \mathrm{c}$ each ; $\$ 2.50 \mathrm{pr}$. doz. White. Early; double. $25 \mathrm{c}$ each; $\$ 2.50$ pr. doz.

\section{EVERGRERNS-MAIL SIZES}

Mail size, postpaid. These are sturdy litt!e plonts, transplanted. They will not give immediate effect of the larger sizes but are uscful when ore cen give them time to grow. They are not balled and burlapped, as this size does not require it. Do not let the roots dry, and plant them firmly.

Arhorvitae, American Pyramidal Each Mail size (12-15 in.) postnaid ....... .50

Arborvitae, Berckman's

Mail size (10-12 in.) postnaid ....... .75

Arborvitae, Globe

Mail size $(10-12$ in.) postpaid ....... .50

Arhorvitae, Goldspire

Mail size (12-15 in.) postpaid ...... .75

Juniper, Irish

Mail size (8-12 in.) postpaid ........ .50

Juniper, Pfitzer's

Mail size (12-15 in.) postpaid ....... .75

Juniper, Sayin

Meil size $(12-15$ in.) postpaid ....... .75

rine, Mugho

Mail size (6-8 in.) postpaid .........5n

Red Codar

Mai. size (12-15 in.) postpaid ........ .50

Red Cedar, Cannart

Mial size $(12-15$ in.) $\ldots \ldots \ldots \ldots \ldots \ldots 1.00$

Red Cedar, Silver

Mial size $(12-15$ in.) $\ldots \ldots \ldots \ldots \ldots \ldots 1.00$

Retinospora plumosa aurea

Mail size (12-15 in.) postpaid ....... .75

Spruce, Norway

Mail size $(10-12$ in.) postpaid $\ldots \ldots \ldots . .50$

\section{FEUIT TPEES, BERRIES, ETC.}

Will be quoted in our catalog. Write for pri.es if you wish them before the catalog is issued.

\section{CANNAS, DAHLIAS, GLADIOLUS}

Will be quoted in our catalog, or by mail on request.

If you Hand this to a Friend, write us a card and we will mail another.

\section{DESCRIPTIVE CATALOG}

mailed you or friends free on request.

\section{ROCK GARDEN BOOKLET}

A brief booklet containing a lot of information in a small space, mailer free. Will be ready for mailing about February 1.

\section{SUCCESS WITH ROSES}

Condensed cultural directions with a descriptive list of varieties, mailed free. Will be ready for mailing about February. 1.

\section{A SUCCESSION OF DAISIES}

Early Elder Daisy.

Late FIder Daisy.

Supreme Daisy.

English Daisy.

Shasta Alaska Daisy.

Korean Daisy.

Three each of above for $\$ 3.00$; six each for $\$ 5.00$.

English and Alaska bloom together, Alaska continuing intermittently until fall.

Supreme is a real acquisition in the list, beginning blooming early in June and continuing as a mass of flowers for a month or more.

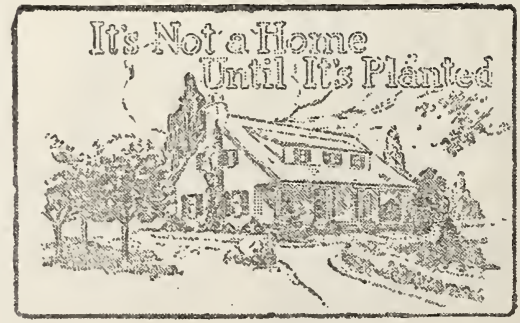

